\title{
Provenance History of Detrital Diamond Deposits, West Coast of Namaqualand, South Africa
}

\author{
David Phillips $^{1}$, Jeff W. Harris ${ }^{2}$ and Mike C.J. de Wit ${ }^{3}$ \\ ${ }^{1}$ The University of Melbourne, Parkville, Australia,dphillip@unimelb.edu.au. \\ ${ }^{2}$ University of Glasgow, Glasgow, Scotland, Jeff.Harris@glasgow.ac.uk. \\ ${ }^{3}$ Tsodilo Resources Ltd, Toronto, Canada, mdewit@tsodiloresources.com.
}

\section{Introduction}

The West Coast of Namaqualand in South Africa hosts extensive detrital diamond deposits, but considerable debate exists as to the provenance of these diamonds. Some researchers have suggested that the diamonds were sourced from the erosion of $>115 \mathrm{Ma}$ orangeites located along the western part of the Kaapvaal craton and transported by the palaeo-'Karoo' river system, to be deposited in the Atlantic ocean near the current outlet of the Olifants river (e.g., de Wit, 1993). Other workers have argued that the majority of Namaqualand diamonds originated from recent erosion of PermoCarboniferous Dwyka glacial deposits (ca.300 Ma), with their ultimate source being pre-Karoo kimberlites in the interior of the Kaapvaal craton (e.g., Moore and Moore, 2004).

In the current study, we analysed clinopyroxene inclusions extracted from a suite of detrital diamonds from coastal deposits along the Namaqualand coast in an effort to constrain the provenance of these diamonds.

\section{Previous Work}

Previous ${ }^{40} \mathrm{Ar} /{ }^{39} \mathrm{Ar}$ analyses of clinopyroxene inclusions extracted from diamonds sourced from the Orapa kimberlite produced a range of apparent ages from the time of kimberlite eruption to $\sim 100 \mathrm{Ma}$ older than this event (Phillips and Harris, 2008). As the ages were significantly younger than inferred diamond formation ages $(>1.0 \mathrm{Ga})$, the ${ }^{40} \mathrm{Ar} /{ }^{39} \mathrm{Ar}$ results were interpreted to indicate significant argon diffusion to the diamond/inclusion interface zone prior to kimberlite emplacement, with $>90 \%$ of radiogenic argon lost during inclusion extraction. Therefore, although this approach does not constrain the time of diamond formation, it provides a novel means of estimating (maximum) kimberlite eruption ages and is useful for constraining the provenance of detrital diamond deposits (Phillips and Harris 2009).

In a subsequent study, we analysed clinopyroxene inclusions from detrital diamonds collected from the west coast of Namibia and Namaqualand, using the ${ }^{40} \mathrm{Ar} /{ }^{39} \mathrm{Ar}$ laser probe dating method (Phillips and Harris, 2009). These analyses yielded maximum ages for the time of emplacement of source kimberlites/orangeites, mostly younger than ca.300 Ma. These data were used to infer diamond provenance from $<300 \mathrm{Ma}$ kimberlites/orangeites located on the Kaapvaal craton. However, these results were too imprecise to ascertain whether the diamonds were sourced from ca.85 Ma Group I kimberlites, $>110$ Ma orangeites, or possibly from both (or other) sources.

\section{Results}

In the current study, clinopyroxene inclusions were extracted from 35 Namaqualand detrital diamonds. ${ }^{40} \mathrm{Ar} /{ }^{39} \mathrm{Ar}$ ages were then determined using a new generation multi-collector ARGUSVI mass spectrometer system capable of ultra-high precision analyses (e.g. Phillips and Matchan, 2013; Phillips et al. 2017). Large inclusions were step-heated in two increments, whereas smaller inclusions $(<200$ $\mu \mathrm{m})$ were fused in single analyses. Of the specimens analysed, 30 of 35 produced measurable signals, giving apparent ages ranging from $121.5 \pm 3.3 \mathrm{Ma}$ to $668.7 \pm 4.9 \mathrm{Ma}(2 \sigma)$. Only six clinopyroxene inclusions yielded (maximum) apparent ages older than $300 \mathrm{Ma}$, with the majority (22 of 30) being $<260 \mathrm{Ma}$. No clinopyroxene inclusions produced ages $<100 \mathrm{Ma}$. 


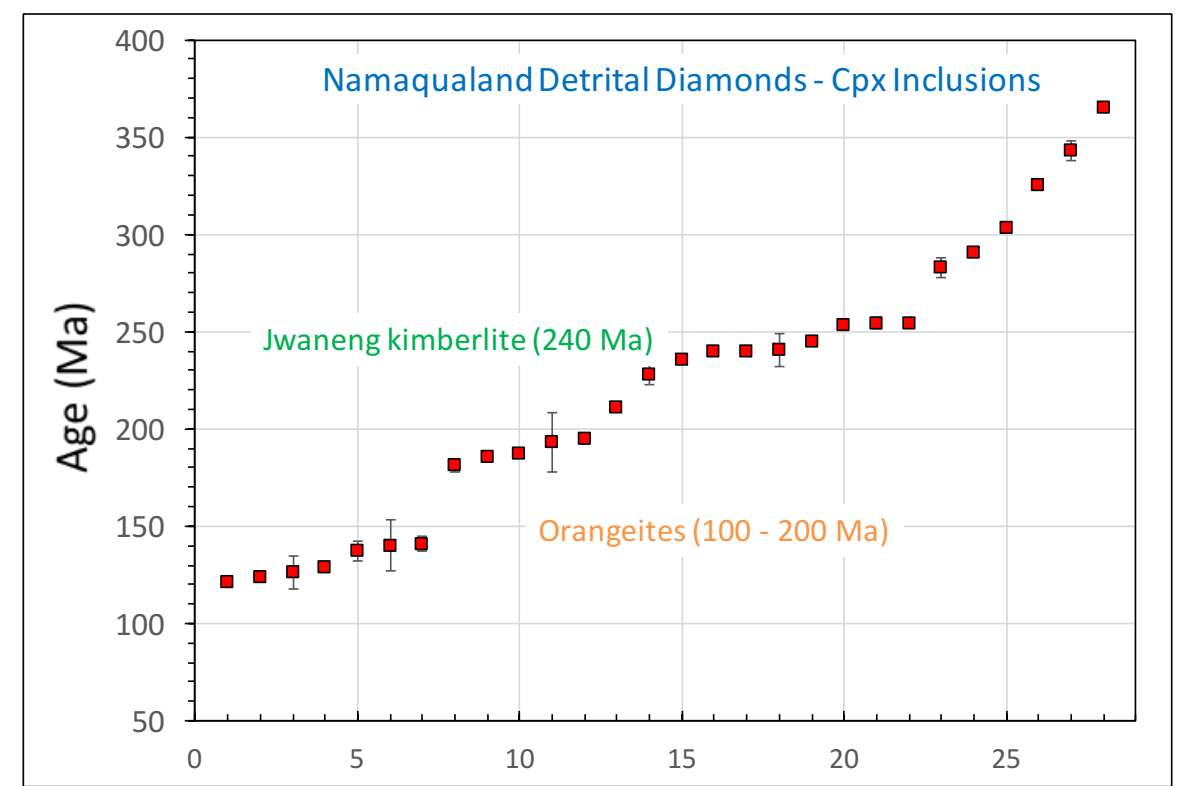

Figure 1. ${ }^{40} \mathrm{Ar} /{ }^{39} \mathrm{Ar}$ apparent ages determined on clinopyroxene inclusions extracted from detrital diamonds sources from Namaqualand coastal deposits (error bars are $\pm 2 \sigma$ ). These ages represent maximum estimates for the time of source kimberlite/orangeite eruption due to the retention of up to $\sim 10 \%$ of pre-eruption argon by the inclusions (see Phillips and Harris, 2009 for details).

\section{Conclusions}

The ${ }^{40} \mathrm{Ar} /{ }^{39} \mathrm{Ar}$ clinopyroxene results confirm that the vast majority of Namaqualand diamonds were sourced from post-Dwyka kimberlites/orangeites. These could include Late Cretaceous Group I kimberlites $(80-90 \mathrm{Ma})$, Cretaceous/Jurassic orangeites $(110-200 \mathrm{Ma})$ and/or early Triassic kimberlites (e.g. 240 Ma Jwaneng kimberlite). However, it is noteworthy that none of the inclusions yielded ages typical of most Group I kimberlites $(80-90 \mathrm{Ma})$. Although these ages are necessarily maxima, the data imply dominant diamond provenance from Cretaceous/Jurassic orangeites rather than Cretaceous Group I kimberlites. This conclusion accords with palaeo-drainage reconstructions in the area, which indicate a change in drainage in the mid-Cretaceous from a southwesterly directed palaeo'Karoo' fluvial system to the current westerly directed Orange river drainage basin (de Wit, 1993).

\section{References}

De Wit MCJ (1993) Cainozoic evolution of drainage systems in the north-western Cape. Unpubl PhD thesis, Univ Cape Town 371pp.

Moore JM, Moore AE (2004) The roles of primary kimberlitic and secondary Dwyka glacial sources in the development of alluvial and marine diamond deposits in Southern Africa. J African Earth Sci 38:115-134.

Phillips D, Harris JW (2008) Provenance studies from ${ }^{40} \mathrm{Ar} /{ }^{39} \mathrm{Ar}$ dating of mineral inclusions in diamonds: Methodological tests on the Orapa kimberlite, Botswana. Earth Planet Sci Lett 274(12):169-178.

Phillips D, Harris JW (2009) Diamond provenance studies from ${ }^{40} \mathrm{Ar} /{ }^{39} \mathrm{Ar}$ dating of clinopyroxene inclusions: An example from the west coast of Namibia. Lithos 112S:793-805

Phillips D, Matchan EL (2013) Ultra-high precision ${ }^{40} \mathrm{Ar} /{ }^{39} \mathrm{Ar}$ ages for Fish Canyon Tuff and Alder Creek Rhyolite sanidine: New dating standards required? Geochim Cosmochim Acta 121:229-239.

Phillips D, Matchan EL, Honda M, Kuiper KF (2017) Astronomical calibration of ${ }^{40} \mathrm{Ar}{ }^{39} \mathrm{Ar}$ reference minerals using high-precision, multi-collector (ARGUSVI) mass spectrometry. Geochim Cosmochim Acta 196:351-369. 